\title{
ENGAGING AND SUSTAINING THE INTEREST OF MALAYSIAN YOUTH TOWARDS THE PALM OIL INDUSTRY
}

\author{
Siti Hamin Stapa ${ }^{1}$ \\ Kesumawati A. \\ Bakar $^{2+}$ \\ ID Fuzirah Hashim ${ }^{3}$
}

\author{
${ }^{1,2,3}$ Center for Research in Language and Linguistics Universiti Kebangsaan \\ Malaysia Selangor, Malaysia. \\ 'Email:sitihami@ukm.edu.myTel: +60192615168 \\ ¿Email:kesuma@ukm.edu.my Tel: +60127755673 \\ ${ }^{s}$ Email:fuzy@ukm.edu.my Tel: +6019388784.2
}

\begin{abstract}
There is no denying that palm oil industry has long been the backbone of Malaysia's economy. It is an industry that continues to be relevant in order to meet both local and global demand for edible oil and biofuel markets. The idea that the industry holds no appeal for youth is a common belief frequently shared by the youth themselves, as well as other stakeholders in agriculture. The key to engaging Malaysian youth and to increase their participation is to first understand their attitude and motivation towards the oil palm sector. This is the first step in understanding the factors underlying their motivation and gauging their level of engagement towards the sector. A set of questionnaires was distributed to 50 FELDA respondents followed by a focus group interview of 5 FELDA youth. Our qualitative data gauged the level of FELDA youth engagement through attitudinal resources while the survey measured the categorical and ordinal level of 8 industry constructs with variables such as gender, age, and education level. In general, the findings revealed insights into palm oil industry's strengths and weaknesses in relation to positive and negative attitude, motivation, and engagement of FELDA youth towards the sector.
\end{abstract}

Article History

Revised: 16 August 2021

Accepted: 20 September 2021

Keywords

Engagement
Sustainability

Palm oil industry

Malaysian youth

Attitude

FELDA.

Contribution/ Originality: The study is one of the few studies which have investigated the interest, engagement and sustainability among Malaysian youth towards the palm oil industry. The paper's primary contribution is finding that they have aspirations to sustain their engagement by building a career in the industry and continuing their family's legacy.

\section{INTRODUCTION}

As the global demand for palm oil rises over the years, the production of palm oil has increased to fulfill the need. Being a pioneer in the production of palm oil, Indonesia produced 41.5 million thousand metric tons of palm oil in 2018/2019. Malaysia however, surpassed Indonesia as the major global exporter in 2020 (Shahbandeh, 2020). Malaysia, being the world's second-largest producer of palm oil, is reliant on the industry to support the country's economy. The industry is the fourth greatest contributor to the national economy, accounting for $8 \%$ of the Gross National Income (GNI) per capita, making it critical to Malaysia's economic development. These statistics have indicated how significant the industry is to the Malaysian economy. Despite the success stories, there are also challenges faced by the government in sustaining the industry's rapid growth.

One of the issues lies in the lack of youth participation in the industry and the agricultural sector due to negative perception related to the risks, weaknesses, costs and the labor intensive nature of the sector (Er et al., 
2021; Hall, 2011). Moreover, when compared with manufacturing and commercial sectors, the agricultural sector is still deemed far inferior and placed in a secondary position. The reason could be attributed to the widespread perception that those who work in agriculture are underpaid and would not have a promising prospect. As a result, youth are generally uninterested in joining the sector. This is indeed worrying as they should be the driving force of a country's economic progress. The lack of youth involvement has resulted in the need to bring in foreign workers to work in the sector. As a result, the palm oil industry in Malaysia relies heavily on migrant labor, which makes up 70 percent of the plantation workforce (Earthworm, 2020).

In Malaysia, FELDA (Federal Land Development Authority) was established to reduce poverty through palm oil and agriculture. As stated by Stapa, Bakar, and Hashim (2019), FELDA currently continues to provide new and suitable facilities so that future generations would have the opportunity to improve their socioeconomic status and wellbeing. However, despite the potential of a product like palm oil, human resources, particularly youth, are considered as one of the factors that could jeopardize the industry's long-term viability in Malaysia. The government has taken the necessary steps to solve this problem, such as providing youth in higher institutions with support services as well as programs and plans for agricultural education (Ministry of Education, 2013).

The 11th Malaysia Plan's economic agenda has included the creation of 1.5 million employments by 2020, focusing on the goal of increasing labor productivity as well as decreasing reliance on less-skilled migrants, both as a result of the ongoing adjustment from intensive economic activity labor to a knowledge and innovation-based economy. In the progress of achieving the goal, the younger generation, particularly FELDA youth must be the driving force for the evolution, making themselves a part of a productive, innovative, imaginative, and highly competitive agricultural community (Norsida, 2012). Having stated that, the focus of this study is to investigate the attitude, engagement, and interest of FELDA youth in the Malaysian palm oil sector, as well as the variables that underpin their attitudes and potentially keep them involved in the industry.

\section{LITERATURE REVIEW}

Agriculture, with government support, offers huge opportunities to entrepreneurs (D'Silva, Shaffril, Uli, \& Samah, 2009). Despite this, there is a strong belief among the general population that agriculture has limited potential. If the industry is managed well however, it can provide good income to farmers and workers (Mohamed, Raja, Kaur, \& Abdullah, 2007). Generally, people in the agricultural industry are confident that the industry can produce high returns because the demand for agricultural products has never decreased. In Malaysia, agriculture provided 7.1\% (RM101.5 billion) to the Gross Domestic Product (GDP) in 2019. In 2020, the Department of Statistics Malaysia reported that palm oil contributed $37.7 \%$ of the total GDP, followed by cocoa and wood products (25.9\%), livestock (15.3\%), fishing (12.0\%), forestation (6.3\%) and rubber (3.0\%) (Department of Statistics Malaysia, 2020). Looking at the promising potential of agriculture in Malaysia, the future generation should consider finding employment in this sector, but it will require effort and commitment.

Siti Hamin, Kesumawati, and Fuzirah (2019) distributed a questionnaire to examine the perception of FELDA youth towards the palm oil sector in Malaysia. The findings showed that the FELDA youth believe in the potential of the industry. They do not only see the potential, but they are also willing to contribute towards the improvement of the sector. The issue is now whether the younger generation will sustain their interest in the palm oil sector. Findings from a study indicated that a majority of the younger generation in the suburbs are not interested in working in the agricultural and plantation sectors (Department of Statistics Malaysia, 2018) because it is cumbersome (Fuzirah, Kesumawati, \& Siti Hamin, 2019; Man, 2008). This is supported by Walsh and Makararavy (2019) who reported that agricultural jobs are regarded as "3D (Difficult, Dirty and Dangerous)". Earlier studies showed that lack of knowledge and skills contributed to the negative perceptions (Frick, 1995; Marlyna, AzianuraHani, \& Er, 2019). Furthermore, Abdullah (2017) claimed that FELDA youth are more likely to become 
involved in high-risk behaviors such as drug abuse and illegal street racing that cause them to lose interest working in the sector.

One of the best ways to sustain the agricultural sector is by creating awareness in the society, especially among the youth as they are the future leaders and inheritors of the world. Youth play a significant part in ensuring a higher quality of urban and rural life in the pursuit of a sustainable tomorrow. Youth also have the power to enact positive change, which is not only limited to the agricultural communities but also to the world. Promoting youth as sustainable agents can lead to a more just, peaceful, inclusive, secure, and sustainable world.

Sustainability means the ability to endure the state and availability of desirable materials or conditions over the long term.

This definition retains the commonly cited characteristics of sustainability and sustainable development as oriented toward

the long term, and the basic identification of sustaining any particular conditions or materials as keeping or maintaining them. (Harrington, 2016).

In maintaining the act of sustainability or sustainable development, the important aim is to preserve or develop favorable environments especially over a period of time. In this study, beneficial conditions include career opportunities, entrepreneurship, and economic stability. Malaysian has made an improvement in the export of palm oil products: for the year 2020 the total export was over RM70 billion, whereas in 2019 it was RM67.5 billion (The Sun Daily, 2021). Despite the challenges faced by the industry throughout the years, the sector's performance has been encouraging. This positive performance should sustain the interest of the youth towards the sector.

Previous studies on the interplay between attitude, motivation and interactions with nature have been associated with cooperative and sustainable intentions and behavior (Kociszewski, 2018). The results of the survey performed by Siti Hamin et al. (2019) has confirmed this relationship. The youth, being part of the palm oil community, are found to be optimistic towards the industry. The longer and the more direct the association or immersion in agriculture is, the stronger the interest. This shows the relevance of positive or negative emotions and behavior towards agriculture in relation to agricultural sustainability.

Youth engagement is a term that describes the participation and identification of youth with palm oil industry and activities, their level of involvement in the industry, their enthusiasm and sense of pride, and their attitudinal and motivational configuration, expressed as positive or negative affect, judgement and appreciation (Kesumawati, Siti Hamin, \& Fuzirah, 2019). Engagement with the industry, expressed as high scores in 8 constructs (social status, manager motivation, industry-person congeniality, co-workers, nature of work, physical working condition, commitment and promotion opportunities) in relation to affect, judgement and appreciation is anticipated to have a favorable effect on sustainable behavior (Kesumawati et al., 2019). In view of the positive influence of engagement, it is reasonable to expect that satisfaction with the industry will also affect sustainable behavior.

\section{METHODOLOGY}

Our study used a mixed method approach for both data collection and analysis. Adopting a sequential explanatory design (Creswell, 2003), this involved two consecutive phases of 1) the collection and quantitative analysis of the questionnaires, followed by 2) the collection and qualitative analysis of two focus group interviews. The former approach involves statistical analysis, the latter, using Appraisal framework (Martin \& White, 2005) allows for a triangulation of findings and a side-by-side comparison in the discussion.

\subsection{Quantitative Research Tool and Procedure}

We used a survey adapted from Kusluvan and Kusluvan (2000) that was translated into Bahasa Malaysia (for easy comprehension) to examine the attitude and motivation of the participants. The survey comprised 71 questions beginning with 7 demographic questions on participants' background. The second part consisted of 64 closed questions to elicit respondents' attitudes and motivation towards Malaysian palm oil sector. Likert scale ranging from "strongly disagree" to "strongly agree" was used to measure the strength of their attitudes. 
The surveys were administered via two representatives to 50 participants from 4 palm oil settlements in Johor and Perak states. Age was used as the parameter for participant selection and youth in Malaysia is defined as any person between the ages of 15 and 40 years old (National Youth Development Policy, 2007). 80\% of our respondents were between 25 to 40 years old. The second biggest group (16\%) ranged from 22 to 25 years old. Male respondents made up $64 \%$ of the participants, while $36 \%$ were female. Once completed, the questionnaires were collected. The data were then analyzed using SPSS Windows 11.5 to measure and compare ranking of percentages, mean scores, and correlation coefficient for determining the relationship between attitude, motivation, and demographic variables.

\subsection{Qualitative Research Tool and Procedure}

Our qualitative data collection employed focus group interviews conducted at Universiti Kebangsaan Malaysia, Selangor. Five FELDA youth of the same age at the Faculty of Social Sciences and Humanities were chosen for the interview. FELDA settlement location formed another participant selection parameter for obtaining experience and opinion from various backgrounds. Split into two sessions, the first focus group interview was carried out with two interviewees and the second session with three. The interviews, 150 minutes in total, were recorded and transcribed. The transcriptions were next categorised for instances of Affect, Judgement and Appreciation from the Appraisal system (Martin \& White, 2005). The categorisation and analysis of lexical items represented as accurate as possible the participants' views and sentiments (e.g., I really love the work I'm doing for the company).

There were two reasons why a mixed method approach was used in this study. Firstly, it offers a systematic integration and interaction of data for examining the link between youth's attitude and motivation towards the palm oil sector in Malaysia with engagement and sustainability. Secondly, the interviews revealed personal insights and new aspects that were not found in the questionnaire. The data from the interview enabled us to identify sociopersonal factors and challenges within the FELDA communities that complemented the results of our quantitative data. Findings are integrated in the interpretation and discussion part of the study.

\section{RESULTS}

Our qualitative data gauged the level of FELDA youth engagement through attitudinal resources while our data from survey instrument measured the categorical and ordinal level of 8 constructs and their relationship with variables such as gender, age, and education level. These two types of data provided validation for each other and created a foundation for drawing conclusions about sustaining youth motivation and engagement in the palm oil sector. We will start by discussing attitude and how positive and negative attitudes could be important indicators of future behavior among individuals (Ajzen, 1985). The definition of Attitude in our study is described as "an evaluative reaction to some referent or attitude object, inferred on the basis the individual's beliefs or opinions" (Gardner, 1985) realised through attitudinal resources denoting positive, neutral, or negative assessment of human behavior, events, objects, circumstances, and feelings (Martin \& White, 2005). The respondents' attitudinal configurations measured as ordinal level towards 8 constructs in the questionnaire were recorded on a Likert scale ranging from 'Strongly agree', 'agree', 'disagree' to 'strongly disagree'. These quantitative results are qualitatively supported by attitudinal expressions of positive or negative affect, judgement, and appreciation to show youth participation and identification with palm oil industry and activities. The results of descriptive statistics see Figure 1 below showed the ranking of positive attitude among the participants towards 8 aspects of the sector.

In the ranking of 8 constructs, social status recorded the highest positive response (3.31). Respondents believed that a career in the palm oil sector is a respectable profession among Malaysians. High positive result suggested that the respondents know their family is proud to see them rise through the ranks and succeed in the industry. In 2018 alone, the industry contributed RM38 billion or 2.8 percent to Malaysia’s GDP. The strength of our palm oil 
industry is a testament to its continuous employment opportunities and the narrowing of the income divide between urban and rural communities.

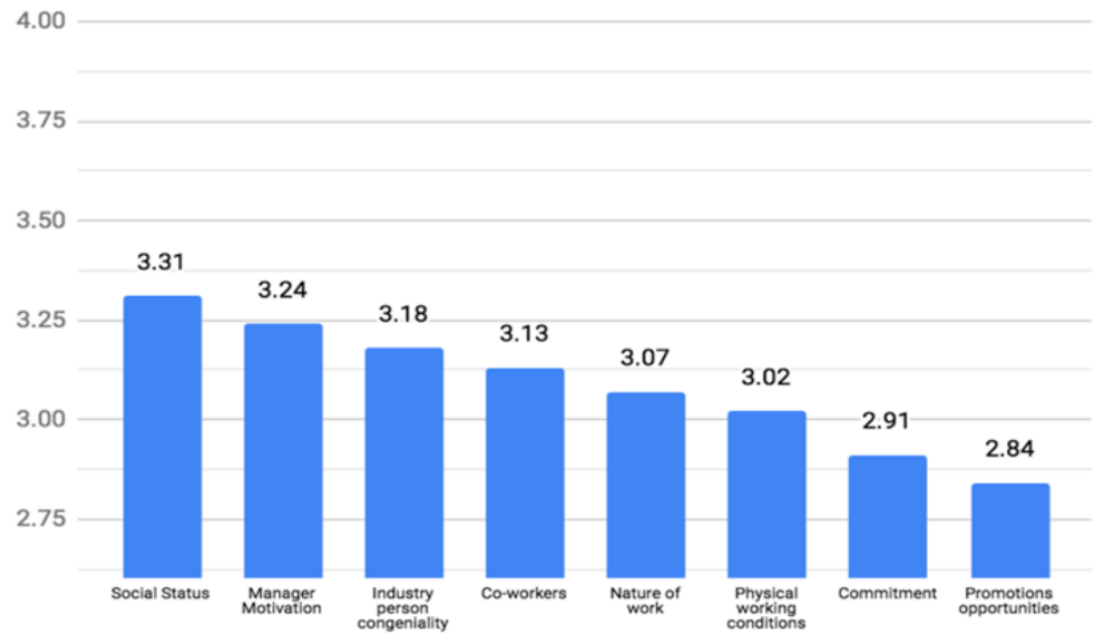

Figure-1. Positive attitude towards 8 constructs of palm oil sector.

The interviews revealed responses that supported our quantitative findings. Four of the FELDA youth agreed that the industry has contributed to and boosted their families' income. One of them commented that "the industry has helped to increase our household income. My friend for example, during the palm oil season... he does not have to worry about how his family's daily needs". Positive appraisal of the industry's strength and the role it plays in providing financial and social support to the locals were recorded from all the interviewees. It could be concluded that the strength of the industry is its stability and continuous development, that have benefitted several generations of settlers and smallholders. The industry has helped families to meet not just their basic needs for food, shelter, clothing, but also educational needs.

A past study found that the ability of managers to lead employees, to foster good relations among staff, to create a harmonious work climate can improve employee attitudes and promote positive behaviors (Abdul Razak, Pangil, Md Zin, Mohamed Yunus, \& Asnawi, 2016). The findings of this study revealed that manager motivation (3.24) ranks the second on positive response among the respondents (see Figure 1).

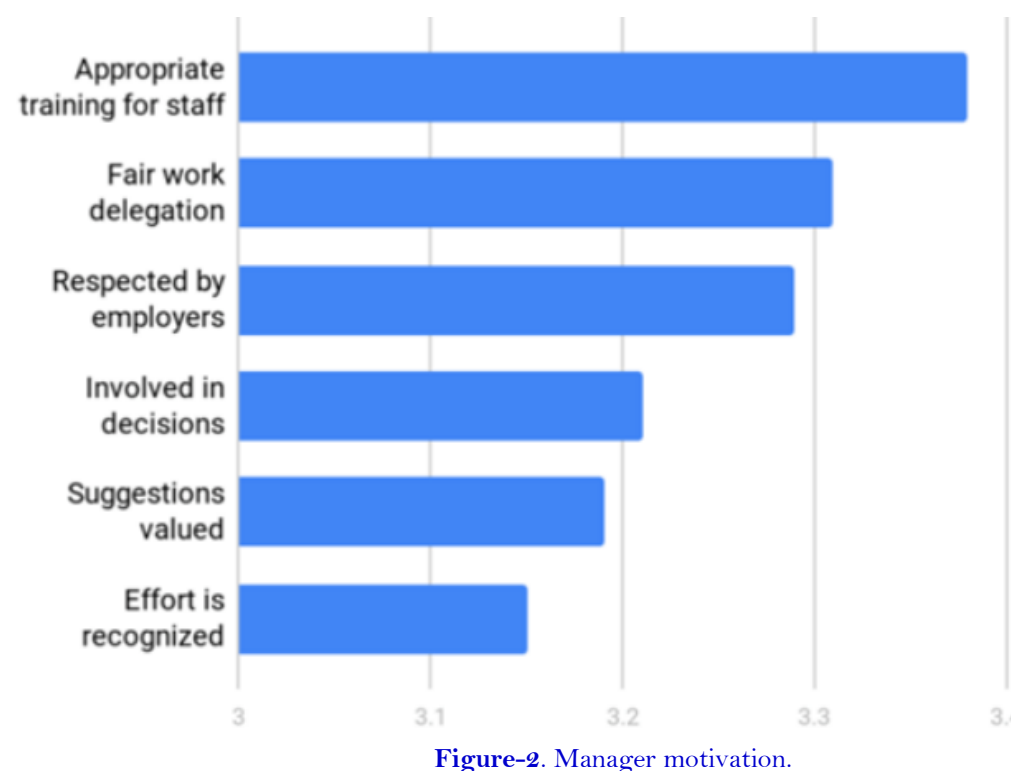


They generally agreed that palm oil managers appreciate their workers and steps were taken to support and provide the staff with appropriate training for their career development. This is the highest ranked feature (3.38\%) in manager motivation see Figure 2. According to the respondents, what raised their motivation were fair and effective work delegation based on individual expertise and skills (3.31\%). Additionally, when it comes to showing respect, respondents generally agreed that employees' suggestions were always valued and taken into consideration (3.29\%). The workers felt valued and motivated when they were involved in decision-making tasks (3.19\%), especially those impacting their careers $(3.21 \%)$ and given training to increase their knowledge and improve their skills. Giving due credit to employees' effort is also one of the factors underlying positive motivation among FELDA staff regardless of age and education background. These results are supported by our interview data through both explicit and implied positive judgements of characters and capability pertaining to behavior and ethics in management. One interviewee described a rapport between her father and his staff as a result of his empathy and good leadership skills, "my father is an employer, but he really takes care of his relationship with his Indonesian workers". The youths also shared personal experience as the third FELDA generation through concrete activities such as house visits, employer-workers interpersonal relations and congeniality between them. These in turn brought about implied evaluations about skills and competencies of FELDA managers. This is very much connected to industryperson congeniality (3.18), in which the participants' expertise and skills are put to good use by their managers, resulting in positive appreciation of their working environment.

Co-workers ranks the fourth highest (3.13) on the measure of positive motivation see Figure 1. Two factors that appear to affect motivation at the workplace are 1) cooperation amongst employees and 2) a friendly work environment. In today's workforce, much of the work is done in teams; besides being able to work independently, one will more often be a part of a team working towards an objective. When co-workers are cooperative and approachable, coupled with adequate educational background and skills, problems are easier to manage and objectives easier to achieve. These are the reasons why most FELDA workers are passionate about working in the sector see Figure 3 below. Additionally, the respondents also expressed positive sentiment towards the work nature of the industry. A career in the palm oil sector is seen as rewarding and self-sustaining.

\section{I can make friends easily with people working in the palm oil industry \\ There is cooperation amongst employees in the palm oil industry

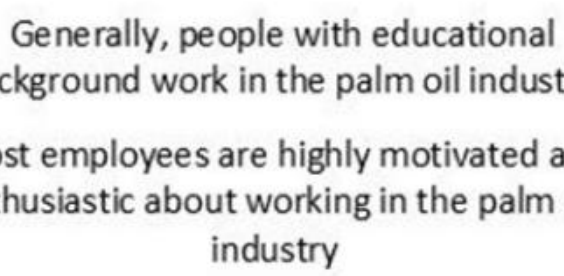

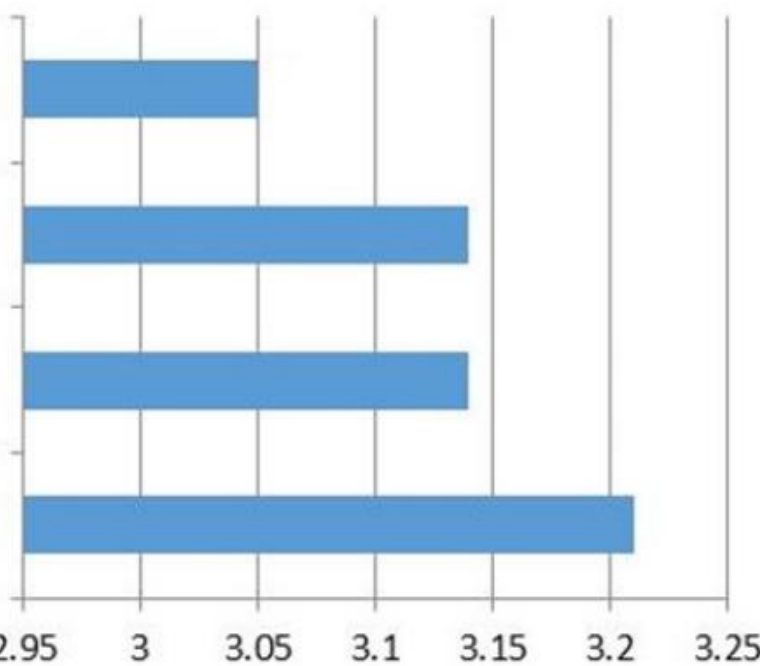

Figure-3. Reasons for Motivation.

When it comes to commitment (2.91) (see Figure 1), both the questionnaire and interview participants stated their interest in a career in agriculture. They expressed the pros and cons of being a part of the palm oil community. Participants in their tertiary level of education stated their preference for working in the palm oil sector once they graduated. They could see the potential of the sector and would encourage their family and friends to join the industry. A variety of positive attitudinal resources were used by the interviewees to explicitly evaluate the 
industry, the management, and the reasons behind their decision. These ranged from positive expressions of happiness and satisfaction to positive evaluation of characters relating to personality, capability, and integrity. The most frequent evaluation by the interviewees was made on the industry in terms of its economic benefits e.g., "palm oil industry helps a lot, especially in terms of the Malaysian economy in further improving the economic status of rural communities in Malaysia", job opportunities e.g., "the industry actually provides various employment opportunities to youths, from high school to university graduates" and effective management. The participants discussed the uses of palm oil in a variety of food, detergents, cosmetic and pharmaceutical products, leading to a continuous demand for both palm and palm kernel oil e.g., "palm oil has a high demand because could be used in a variety of side products especially food". This encourages the growth of side industries that boosts the economy and creates job openings for the community either in the plantations or related businesses. The participants believed that the industry's strength lies in its demand, leading to its sustainability and stability as well as benefitting a few generations of smallholders.

Despite this optimistic outlook, there appears to be an aversion and disengagement among the youth towards the sector. Negative attitude is implied through concrete examples. They believed that working days are lengthy and laborious in the plantation under the scorching sun e.g., "the work is labor intensive - it is difficult because one has to cut the fruit clusters with a chisel and sickle, and then collect and load them on the truck". Additionally, irregular income is also a problem as it is subject to the fluctuating palm oil market value. However, challenging work conditions and laborious hours could be alleviated through innovative harvesting methods and technologies, that could subsequently improve efficiency and increase productivity.

Interestingly, criticisms were also made both directly and indirectly towards local youth's attitudes - "Our youths are problematic" and "they are very choosy when it comes to finding jobs". It could be inferred that disengagement might also be an issue of character, and not only due to the nature of the industry. This could be because our young people do not understand the industry and how they can contribute to it. Having been raised within the palm oil community, positive attitude and high motivation could be felt in the answers given by the questionnaire respondents and the interviewees. They explicitly commended the industry, "the industry has survived until now and has greatly helped many generations of smallholders" and praised the government for the financial support, training, scholarship and education opportunities given to the community. Our subjects have a deep personal connection with the industry, and they feel proud to be carrying on the legacy of hard work and stewardship of the plantation. This is significant considering the declining years and capacity of the pioneers in managing the plantations. The interviewees felt strongly that the future generation has the capability to manage inherited FELDA lands through proper guidance and management. Unfortunately, lack of industry knowledge as well as seeking greener pastures, have led our young people to relocate to urban areas, pursuing career choices that differ from their parents'. This could also be due to their higher qualification; they therefore seek better-paying jobs. This result confirms an earlier study that agriculture is an unappealing career option because of low wages of its employees (Abdullah. \& Sulaiman, 2013).

On the whole, both quantitative and qualitative data analysis have given some insights into the industry's shortcomings and strengths in relation to engagement and motivation of youth in the FELDA community.

\section{DISCUSSION AND CONCLUSION}

In general, both our quantitative and qualitative data have indicated that FELDA youth have strong interest and feel committed towards the palm oil sector. For positive attitude, the results reported that the highest rank is social status. Next are manager motivation, industry-person congeniality, co-worker motivation, work nature, physical working condition, commitment and finally, promotion opportunities.

The respondents value the importance of palm oil industry to their generation and future FELDA generation, thus they have the aspiration to sustain their engagement in this industry. They expressed their interest in continuing their family legacy and build a career in the industry. Izard and Ackerman (2000) claimed that intrinsic 
motivation can be sparked and maintained through interest, and it "motivates exploration and learning, and guarantees the person's engagement in the environment”. Thus, when the youth are motivated, they will perceive their jobs as being meaningful. Their interest will be sustained and consequently, engagement towards the industry will be increased.

The palm oil industry certainly provides promising career pathways for youths. The President of Malaysian Palm Oil Association assured that oil palm estate workers do not need to be afraid about job loss because the sector is still thriving. He further claimed that he had not heard of any retrenchments even in difficult times (Malaysian Palm Oil Council, 2020). According to Abazue, Er, Alam, and Begum (2015), oil palm farming provides jobs and possibilities to many people and, if effectively handled, has the ability to alleviate unemployment and poverty, particularly in rural regions. The fact is, within the last 30 years palm oil industry has thrived diversely, providing a range of job opportunities. Research and development, engineering, agribusiness, and communications offer important positions to job seekers. The FELDA youth in our study in fact regarded jobs in the industry as rewarding and self-sufficient. Another factor underlying engagement towards the industry is manager motivation. High levels of engagement between managers and employees have proven to increase productivity and profitability while decreasing employee turnover (Osborne \& Hammoud, 2017). It is believed that organizations would be more successful when they treat their employees as stakeholders of their own future.

We found that the respondents also highlighted negative factors within the industry. Despite the negative attitude expressed by a small percentage of the participants through the survey and the interview, our data reveal that they are predominantly more positive than negative. The underlying reason could be the undeniable fact that palm oil is one of Malaysia's major contributors, inspiring the youth to pledge their commitment to the industry. The Young Professionals for Agricultural Development (2017) proposed that measures have to be taken to ensure the sustainability of palm oil and other parts of agriculture. The first measure is by linking social media to agriculture, as social media would be a good channel to attract and engage young people to agriculture through online training and activities. Social media has been proven useful in reaching out to the younger generation as it is a big part of their life now. Next is to improve agriculture's image, specifically palm oil as a fresh and contemporary sector. The awareness of the benefits of this sector needs to be raised amongst the youth. Agriculture should no longer be regarded as a $3 \mathrm{D}$ job sector, but instead a sector with a growing reputation. Courses in agriculture and palm oil should be strengthened in institutions of higher learning whereby taught courses could be linked to advances in technology, with a focus on agribusiness and entrepreneurship. With this, the young generation would be able to develop their prospect in these areas. Highlighting these opportunities, as well as conducting courses at higher institutions to raise awareness about the industry's potential maybe effective in encouraging engagement and sustaining interest among our new graduates.

Increased usage of Information and Communication Technologies (ICT) is another measure to help youth spread knowledge, build networks, and find employment. Such technologies would also uplift the livelihoods of the rural farmers and increase palm oil profitability. As the findings have revealed, provision of financial support, training, scholarship, and education opportunities have greatly assisted our FELDA youth; however, in order for palm oil industry to be transformed considerably, barriers to their engagement in this industry such as financial support and low wages need to be addressed. Policy discussions at all levels need to include youth as meaningful youth participation, provides real opportunities for them to become involved in decisions that affect their lives and their communities. To remain competitive and to entice young people to join the industry, employers have to offer higher salaries and better benefit packages. Most of our respondents conveyed positive evaluation concerning the sector's prospect. They believed that by continuing to invest in research and technology, the sector might expand and improve the quality of its products, thus increasing market demand of the products. As a result, higher youth participation in the sector could be expected especially among the locals. 
Funding: This study is funded by the Malaysian Palm Oil Board under Grant No. EP-2016033. We would like to extend our sincere gratitude and appreciation to the participants from Universiti Kebangsaan Malaysia who provided useful information and opinions into the industry and its community.

Competing Interests: The authors declare that they have no competing interests.

Acknowledgement: All authors contributed equally to the conception and design of the study.

\section{REFERENCES}

Abazue, C., Er, A., Alam, A. F., \& Begum, H. (2015). Oil palm smallholders and its sustainability practices in Malaysia. Mediterranean Journal of Social Sciences, 6(6 S4), 482-482. Available at: https://doi.org/10.5901/mjss.2015.v6n6s4p482.

Abdul Razak, N., Pangil, F., Md Zin, M. L., Mohamed Yunus, N. A., \& Asnawi, N. H. (2016). Theories of knowledge sharing behavior in business strategy. Procedia Economics and Finance, 37, 545-553. Available at: https://doi.org/10.1016/S2212-5671(16)30163-0.

Abdullah, S. (2017). Second sphere: Better education for felda youth. The Edge Malaysia. Retrieved from: https://www.theedgemarkets.com/article/second-sphere-different-kind-political-coalition.

Abdullah., A. A., \& Sulaiman, N. N. (2013). Factors that influence the interest of youths in agricultural entrepreneurship. International Journal of business and Social science, 4(3), 288-302.

Ajzen, I. (1985). From intentions to actions: A theory of planned behavior. In J. Kuhl \& J. Beckmann (Eds.) action control (pp. 11-12). Springer: Berlin, Heidelberg.

Creswell, J. W. (2003). Research design: Qualitative, quantitative, and mixed methods and approaches. USA, Thousand Oaks: Sage Publications.

D’Silva, J. L., Shaffril, H. A. M., Uli, J., \& Samah, B. (2009). A review of contract farming and factors that impinge youths acceptance to contract farming. European Journal of Social Sciences, 11(2), 328-338.

Department of Statistics Malaysia. (2018). The performance of state's economy, 2017. Retrieved from: https://www.dosm.gov.my/v1/index.php?r=column/ctheme\&amp;menu_id=TE5CRUZCblh4ZTZMODZIbmk2aW RRQT09\&amp;bul id=L25EUXOxbWdBaEVoWXU5aTFOWUpNdz09. [Accessed December 5, 2020].

Department of Statistics Malaysia. (2020). Selected agricultural Indicators, Malaysia, 2020. Retrieved from: https://www.dosm.gov.my/v1/index.php? r=column/cthemeByCat\&amp;cat=72\&amp;bul_id=RXVKUVJ5TitHMOc wYWxlOHcxU3dKdz09\&amp;menu_id=ZoVTZGU1UHBUT1VJMFlpaXRRRoxpdz09/. [Accessed December 5, 2020].

Earthworm. (2020). How migrant workers and palm oil businesses can achieve stability together.

Er, A. H. C., Sharifah, R. S. A. R., Dira, S. B. D. S., Nur Marina, I., Auni, A. M. N., Noordeyana, T., . . Marlyna, M. (2021). Environmental care strategies by a palm oil miller. Annals of the Romanian Society for Cell Biology, 3062-3080.

Frick, M. J. (1995). Rural and urban inner-city high school student knowledge and perception of agriculture. Journal of Agricultural Education, 36(4), 1-9. Available at: https://doi.org/10.5032/jae.1995.04001.

Fuzirah, H., Kesumawati, A. B., \& Siti Hamin, S. (2019). Attitudes and motivation of the young generation towards the palm oil industry. e-Bangi, 16(4), 1-17.

Gardner, R. C. (1985). Social psychology and second language learning: The role of attitudes and motivation. Great Britain, London: Hodder Arnold.

Hall, T. (2011). Can agriculture solve youth unemployment? The Gleaner. Retrieved from: http://jamaicagleaner.com/gleaner/20110131/cleisure/cleisure4.html.

Harrington, L. M. B. (2016). Sustainability theory and conceptual considerations: a review of key ideas for sustainability, and the rural context. Papers in Applied Geography, 2(4), 365-382. Available at: https://doi.org/10.1080/23754931.2016.1239222.

Izard, C. E., \& Ackerman, B. P. (2000). Motivational, organizational, and regulatory functions of discrete emotions. In M. Lewis \& J.M. Haviland-Jones (Eds.)., Handbook ofEmotions (pp. 253-264): Guilford Press. 
Kesumawati, A. B., Siti Hamin, S., \& Fuzirah, H. (2019). "Pemuda zaman kini sangat memilih kerja": An appraisal analysis of FELDA youth's attitudes towards the palm oil industry. Linguistics Journal, 23(2), 21-40.

Kociszewski, K. (2018). Sustainable development of agriculture: Theoretical aspects and their implications. Economic and Environmental Studies, 18(3), 1119-1134. Available at: https://doi.org/10.25167/ees.2018.47.5.

Kusluvan, S., \& Kusluvan, Z. (2000). Perceptions and attitudes of undergraduate tourism students towards working in the tourism industry in Turkey. Tourism Management, 21(3), 251-269. Available at: https://doi.org/10.1016/So2615177(99)00057-6.

Malaysian Palm Oil Council. (2020). Jobs secure in oil palm plantations. Retrieved from: http://mpoc.org.my/jobs-secure-in-oilpalm-plantations. [Accessed December 5, 2020].

Man, N. (2008). Perceptions of agriculture among agricultural youth and the need for agricultural education. Malaysian Youth Development Journal, 1, 99-114.

Marlyna, M., AzianuraHani, S., \& Er, A. H. C. (2019). Youth's attitude in the palm oil industry in Malaysia: A needs analysis. Academics. Journal of Southeast Asian Studies, 89(1), 175-189.

Martin, J. R., \& White, P. R. R. (2005). The language of evaluation. Gordonsville, United States: Palgrave Macmillan.

Ministry of Education. (2013). Malaysian Education Blueprint 2013-2025. Kementerian Pendidikan Malaysia. Retrieved from: https://www.moe.gov.my/menumedia/media-cetak/penerbitan/dasar/1207-malaysia-education-blueprint-20132025/file.

Mohamed, A. F., Raja, A. N. M., Kaur, B., \& Abdullah, A. M. (2007). 50 years of Malaysian agriculture: The agricultural community. Selangor, Serdang: Universiti Putra Malaysia Press.

National Youth Development Policy. (2007). National youth development policy. Retrieved from: https://www.youthpolicy.org/national/Malaysia_1997_National_Youth_Development_Policy.pdf.

Norsida, M. (2012). Unleashing youth potentials in developing the agricultural sector. Pertanika Journal of Social Sciences and Humanities, 20(1), 93-106.

Osborne, S., \& Hammoud, M. S. (2017). Effective employee engagement in the workplace. International Journal of Applied Management and Technology, 16(1), 50-67. Available at: https://doi.org/10.5590/ijamt.2017.16.1.04.

Shahbandeh, M. (2020). Palm oil industry worldwide- statistics \& facts. Statista. Retrieved from: https://www.statista.com/topics/6079/global-palm-oil-industry.

Siti Hamin, S., Kesumawati, A. B., \& Fuzirah, H. (2019). Attitudes \& motivation of the young generation towards the palm oil industry. Mediterranean Journal of Social Sciences, 10(1), 117-130. Available at: https://doi.org/10.2478/mjss-20190012.

Stapa, S. H., Bakar, K. A., \& Hashim, F. (2019). Attitudes and motivation of the young generation towards the palm oil industry. Mediterranean Journal of Social Sciences, 1O(1), 117-1130. Available at: https://doi.org/10.2478/mjss-2019-0012.

The Sun Daily. (2021). Palm oil, palm products export value for 2020 to surpass RM70 billion. Retrieved from: https:// www.thesundaily.my/business/palm-oil-palm-products-export-value-for-2020-to-surpass-rm70-billion-FG5945337.

Walsh, J., \& Makararavy, T. (2019). Cambodian migrants in Thailand: Working conditions and issues. Asian Social Science, 7(7), 23-29. Available at: https://doi.org/10.5539/ass.v7n7p23.

Young Professionals for Agricultural Development. (2017). Ypard. Retrieved from: https://ypard.net/news/9-ways-engageyouth-agriculture.

Views and opinions expressed in this article are the views and opinions of the author(s), International Journal of Asian Social Science shall not be responsible or answerable for any loss, damage or liability etc. caused in relation to/arising out of the use of the content. 